\title{
Accurate Solution to Brain Wave Disorders
}

\author{
Manisha Joshi Chandajkar* \\ Director, Ayurbrain Learning Convent Street, Shahid Bhagat Singh Marg, Colaba, Mumbai, Maharashtra, India \\ *Corresponding author: Manisha Joshi Chandajkar, Director, Ayurbrain Learning Convent Street, Shahid Bhagat Singh Marg, Colaba, Mumbai, Maharashtra, India, Tel: \\ 919096945845; E-mail:ayurbrain@gmail.com
}

Received date: January 23, 2017; Accepted date: January 27, 2017; Published date: February 10, 2017

Copyright: @ 2017 Chandajkar MJ. This is an open-access article distributed under the terms of the Creative Commons Attribution License, which permits unrestricted use, distribution, and reproduction in any medium, provided the original author and source are credited.

\begin{abstract}
In ancient period, learning method was memorizing only. So it was utmost important to have good attention and retention of knowledge.

Students who used to lag behind were treated with Ayurveidic Herbs to improve comprehension. So my aim about this research was to shed light on these herbs and to test its validity with modern methods and take advantage of new technology. Also concept of medha-intelligence in Ayurveda and concept of MEDHYA rasayanaintelligence enhancing herb has been studied thoroughly in this experiment.
\end{abstract}

Keywords: Ayurveidic; Brain disorder; Brain waves

\section{Review}

Ayurveda, the life science, focuses on root causes of any disorder. Ayurveda says any disorder is imbalance of factors essential for health. So accurate solution is correcting the imbalance. According to Ayurveda all brainwave disorders are imbalance of prana [1].

PRANA is electrical oscillations i.e. brain waves. A small deviation in PRANA can cause multifold effect on mind and body. So balancing the electrical environment is essential step to have good health.

Today everyone seems to be stressed. Stress is sensory overload. Ayurveda says STRESS creates disturbance in oscillations of PRANA. So the frequency that will slow down oscillations of prana will help to reduce stress [2-4].

Ayurveda suggests a group of herbs that acts on different brainwave disorders, called as Medhya Rasayana. My speciality is in effect of Medhya rasayana on brainwaves. I did my research on nardostachys jatamansi dc. I studied effect of jatamansi on brainwaves [5].

Jatamansi is Himalayan herb. It acts on brainwaves biphasic. It balances Dopamine neurotransmitter and enhances GABA neurotransmitter. Hence it is anxiolytic and calms brain. Jatamansi, according to Ayurveda, is Akash gunatmak. It controls sensory overload especially caused by overthinking [6,7]. Also its Snigdha Guna nourishes myelin sheath which in turn allows oscillations of prana (impulse) to travel unobstructed.

Ayurveda says Medhya Rasayana is rejuvenating herbs for brain health. Rejuvenation is reverse process of aging. All these herbs act on prana and neurotransmitters to achieve balance.

Philosophy of Ayurveda is to prevent disease than to cure it. For prevention of brainwave disorders Medhya Rasayana are next big thing. May it is sleep disorder, ADHD, Anxiety, depression, epilepsy etc. Ayurveda has profound knowledge to achieve health. Research in Ayurveda is gamete of applied technology and ancient wisdom.
I use advanced technology in order to analyze brainwaves and interpret it in terms of Ayurveda in order to treat the disorder in most scientific way [8].

So how I did research, I used double blind method, I made three groups one group received jatamansi tablet, second group received placebo and third group was control group. This research was performed on school students of age 12 to 14 years old. I gave jatamansi to 300 students for two months and the parameters used were EEG and four factors of guildford test-concentration, cognition, convergent thinking and memory.

I also analyses authenticity of Jatamansi by Agharkar Institute Pune. Also did toxicological study on mice to decide dose of jatamansi.

A sum of 300 students were randomly selected. Pre and Post EEG were recorded by neurologist DR. Rahul kulkarni, before and after experiment. Also pre and post guildford test was conducted by MENSA-dnyan prabhodini Pune.

Daily observations were noted. After experiment statistical analysis was done. Effect of jatamansi in reducing pre exam anxiety, convergent thinking and concentration was significant.

Jatamansi improved synchrony of brainwaves in frontal lobe. This improves executive function of frontal lobe in order to reduce or control stress factors.

Synchronized brainwaves are essential while learning. Jatamansi synchronizes brainwaves. Hence learning disorders can be cured by correcting brainwave disorders with the help of herbs $[9,10]$.

Everybody can enjoy benefits of jatamansi. Take jatamansi rhizome, keep it in glass full of Luke warm water and keep it aside for whole night and then filter it, in the morning and drink this jatamansi infused water, you can add honey in it to taste it pleasant.

\section{References}

1. Agnivesha D (1993) Charaka Samhita Part 1 and 2, (edtn 19th) Chokhamba Bharti Academy, Varanasi, India. 
2. Arundata H (1982) Sarvangasundari and Ayurveda Rasayana, Comm. on Ashtanga Hridaya". Chokhamba Orientalia, Varanasi, India.

3. Bhatta N, Samhita H (1963) Guj. Comm, (1st edtn) Sastu Sahitya Press, Ahmedabad, India.

4. Nagarjuna N (1976) Rasa Visheshika Sutra, Muthuswami publication Division, Government Ayurveda College, Trivendrum, India.

5. Bhel (1997) Bhela Samhita. C.C.R.I.M.H. New Delhi, India.

6. Chakrapanidatta (1939) Bhanumati Vyakhya on "Sushruta Samhita" (Sutrasthana). Shri. Swami Laxmi Ramidhi Granthamala Prakashana Series, I, Published by Shyamasundar.
7. Charapnidatta (1994) Ayurvedadipika Sam. Comm. in Charakasamhita. Nirnaya Sagara Press, Bombay, India,

8. Chakrapanidatta (1961) Chakrdatta, Choukhambha Sanskrita Series, (3rd edtn) Varanasi, India.

9. Choube Dattaram Abhinava Nighantu" Part 2, (2nd edtn).

10. Choudhari RC (1985) Aabhinava Manoroga Vigyana. Choukhambha Orientalia. 